\title{
EFFECT OF PRE- AND POSTHARVEST TREATMENTS ON FLOWER LONGEVITY OF CUT ROSE CV. 'GRAND PRIX'
}

\author{
AMAL A. ZAKY \\ Ornamental Plants Res. and Landscape Dep., Hort. Res. Inst., ARC, Giza, Egypt
}

(Manuscript received 7 April 2013)

\begin{abstract}
Roses (Rosa hybrida L.) are one of the most important speciality cut flowers produced. The present experiment focuses on the effects of pre and postharvest treatments on postharvest longevity and other related characters of 'Grand Prix' cut roses. The results emphasized that the individual treatments with either Ca or NAA at preharvest + either Florissant-400 or silicon at postharvest significantly prolonged vase life, increased the percentage of flower opening and water uptake of rose cut flowers. Moreover, the combined treatments of $\mathrm{Ca}+\mathrm{NAA}$ at preharvest +Florissant400 had a superior effect on extending life of flowers, increasing flower diameter $(\mathrm{cm})$ and flowers fresh weight percentage. The treatment of control at preharvest plus Florissant-400 or silicon at postharvest gave the highest percentage of bent-neck at 9 days with values higher than $86 \%$, whereas the combination between $\mathrm{Ca}+\mathrm{NAA}$ at preharvest + either Florissant-400 or silicon at postharvest recorded the highest delay for bending symptoms. Preharvest application of $\mathrm{Ca}+\mathrm{NAA}+$ either Florissant-400 or silicon at postharvest had the highest effect on reducing the depletion of sugars content and increasing anthocyanin content in flowers. The individual treatments with NAA at preharvest + either Florissant-400 or silicon at postharvest occupied the second rank in its effect on the studied characters, thus keeping the quality of flowers compared to the other used treatments and control.

Key words: Rose cut flowers - pre and postharvest treatments - vase life - Bent-neck phenomenon.
\end{abstract}

\section{INTRODUCTION}

Roses (Rosa hybrida L.) common name rose, a large number of widely grown, deciduous, shrubby species. The most important ornamental species of the Rosaceae family are recognized for their high economic value and are used in agro-based industries, especially in cosmetics and perfumes. Additionally, roses play a vital role in the manufacturing of various products of medicinal and nutritional importance. However, roses are mainly cultivated for the commercial production of their cut flowers, which constitutes a considerable portion of the floriculture business. Vase life of rose cut flowers is usually short. Cut flowers wilt and the floral axis becomes bent below the flower head (bent-neck). The development of such symptoms is considered 
to be caused by vascular occlusion, which inhibits water supply to the flowers. Preharvest conditions influence the quality of cut flowers in the range of 30 to $70 \%$ (Halevy, 1979). The cut flower quality, not achieved in the preharvest phase, such as length, thickness and firmness of stems, size and color of flower organs, will not be recovered during postharvest processes.

Synthetic auxins have shown to prevent flower abscission (Van Doorn and Stead, 1997) which is a problem in rose production. Premature bent-neck can be avoided by calcium applications which stabilize cell walls and regulate membrane permeability in rose peduncles (Marschner, 1986).

Calcium $\left(\mathrm{Ca}^{+2}\right)$ is an important element that is essential to living organisms and to plant growth and development. Some of these benefits include stronger cell walls because it is a major component in the cell wall of most plants in the form of $\mathrm{Ca}$ pectate thus increases postharvest life of flowering plants as well as promotes bud opening (Michalczuk et. al., 1989).

Silicon (Si) plays an important role in agricultural and natural environments in the alleviation of a broad range of plant stresses. It is well known that optimization of plant silicon $(\mathrm{Si})$ nutrition reinforces plant resistance against biotic and abiotic stresses. Traditionally, it is suggested that an accumulation of $\mathrm{Si}$ in the epidermal tissue of the plant is the main mechanism which provides defense against insect and fungal attacks. The chemical properties of monosilicic acid maintain plant protection against the effects of heavy metals contamination. In addition, potassium silicate has shown great potential in controlling postharvest green mould of citrus fruits when applied pre or postharvest or both (Abraham et. al., 2008).

Florissant-400 (4 ml/l) treatment for Eucalyptus parvifolia reduced ethylene production and increased vase life (Ferrante et. al., 1998)

The main objective of this study was to determine the best pre and postharvest treatments to prevent the bent-neck phenomenon and to analyze possible interactions among different preharvest treatments on commonly used postharvest treatments in order to improve the keeping quality of cut rose cv. 'Grand Prix'.

\section{MATERIALS AND METHODS}

This research was carried out at Ornamental Plant Research and Landscape Department, Horticultural Research Institute, Giza, Egypt during two successive seasons (2011 and 2012). Rosa hybrida L. cv. 'Grand Prix' (red coloured) were grown in plastic greenhouse. The experiment was divided in two phases: First phase (preharvest): The plants were treated with (1) $0.017 \%$ Ca as calcium chelate applied 
3, 2 and 1 weeks before harvest and (2) 8 ppm a-naphtalene acetic acid (0.05\% Hormonagro NAA) sprayed one week before harvest onto the upper third of the plants, (3) Calcium + NAA, calcium chelate applied 4,3 and 2 weeks before harvest and NAA one week before harvest, (4) control without preharvest applications. Second phase (postharvest): Rose flowers were harvested in the morning and immediately taken to the laboratory. Pre-cooling of flowers was performed by placing them in ice cold water for 3 hrs which removes the field heat and greatly improves quality and enhances the vase life of cut flowers. The flowers were selected for uniformity in terms of development, the stems were trimmed to an equal length $(60 \mathrm{~cm})$. The flowers were placed in a vase $(500 \mathrm{ml})$ containing $400 \mathrm{ml}$ holding solution with (1): 1- Florissant-400 $(0.35 \mathrm{ml} / \mathrm{l})$ which contains QUAT-Bactericide (non-chlorine based) + sucrose $(2 \%)+8$ - Hydroxyquinoline citrate $(\mathrm{HQC})$ at $200 \mathrm{ppm}$.

2- Silicon $(2 \mathrm{gm} / \mathrm{l})+$ sucrose $(2 \%)+8$ - hydroxyquinoline citrate $(\mathrm{HQC})$ at $200 \mathrm{ppm}$.

Under lab conditions of $22 \pm 2 \mathrm{C}, 50-60 \% \mathrm{RH}$ and $24 \mathrm{hrs}$ light with fluorescent lamps to complete vase life.

\section{Measurements:}

1- Flower vase life (days) was determined when the petals show symptoms of wilting and change of color edge of petals.

2- Flower opening percentage.

3- Flower diameter (cm).

4- The percentage of increase in fresh weight during vase life.

5- Water uptake $\left(\mathrm{cm}^{3}\right)$.

6- Bent-neck phenomenon (\%).

7-Total sugars (\%) in flowers were determined colorimetrically according to the method described by Dubois et al., (1956).

8- Anthocyanin (\%) in flowers was determined colorimetrically according to Husia et al (1965).

Layout of the experiment was completely randomized design in a $4 \times 2$ factorial arrangement with three replicates, each replicate contained 4 flowers.

Statistical analysis

The obtained data were statistically analyzed according to Snedecor and Cochran (1989) and means were compared by New Least Significant Difference (New L.S.D) test at the $5 \%$ level of probability in the two seasons. 


\section{RESULTS AND DISCUSSION}

\section{Effect of pre and postharvest treatments and their interactions on flower traits of Rosa hybrida L. cv. 'Grand Prix' under room conditions:}

\section{1- Flower vase life:}

Data shown in Table (1) reveal that the highest flower longevity was obtained with the treatments of $\mathrm{Ca}+\mathrm{NAA}+$ Florissant-400 and $\mathrm{Ca}+\mathrm{NAA}+$ silicon with 21.30, 19.47 and $20.30,19.80$ days, respectively in both seasons with significant differences. This vase life was much higher than the other treatments. On the other hand, the preharvest applications of only control (+either Florissant-400 or silicon at postharvest) showed a shorter vase life of $11.20,9.57$ and 10.30, 8.42 days, respectively) in both seasons with significant differences. Combining NAA as preharvest application plus all postharvest treatments induced highly significant increase in flower vase life when compared to Ca pretreatment in both seasons. These results are in harmony with those of Bolivar et al (1999) on 'Ariana' cut roses who pointed out that the longest vase life was obtained with the treatments of $\mathrm{Ca}+\mathrm{NAA}$ + Chrysal with 11.4 days compared to the control (7.3 days). Khenizy et al (2009) on Moluccella laevis stated that pulsing basal ends of cut flowers in a solution containing sucrose $(30 \mathrm{~g} / \mathrm{l})+8$-HQC $(250 \mathrm{mg} / \mathrm{l})+\mathrm{Ca}(200 \mathrm{mg} / \mathrm{l})+\mathrm{Ca}^{+2}$ chelator (EDTA) $(30 \mathrm{mM} / \mathrm{l})$ $+\mathrm{BA}(25 \mathrm{mg} / \mathrm{l})$ was the most effective treatment for increasing vase life.

\section{2-Flower opening (\%)}

Generally presented data in Table (1) show that the percentages of flowers opening were significantly varied due to the pre- and postharvest treatments. In this connection, all pre- and postharvest treatments increased the flowers opening percentage which proved its superiority in the treatment of $\mathrm{Ca}+\mathrm{NAA}+$ Florissant-400 compared to control in both seasons. The flowers treated with $\mathrm{Ca}+\mathrm{NAA}+$ Florissant400 and $\mathrm{Ca}+\mathrm{NAA}+$ silicon presented the highest flowers opening percentage since they attained $100 \%$ opening in both seasons, whereas the lowest flowers opening percentages (68.45 and $65.28 \%$, respectively) were observed with control + silicon at postharvest in both seasons. The combination treatments between preharvest treatments + Florissant-400 induced the highest flower opening percentages in both seasons. These results agreed with those of El-Saka (2002) who pointed out that holding Rosa hybrida cut flowers in Florissant- $600+20 \mathrm{~g} / /$ sucrose increased flowers opening percentage. Michalczuk et al (1989) revealed that Ca applied as Ca (NO3)2 lengthened vase life of rose cut flowers and promoted bud opening. 


\section{3- Flower diameter}

The diameter of flower is very important parameter as it is desirable to produce the biggest flowers for using in arrangement. From data presented in Table (1) it is clear that the greatest flower diameter was obtained from the treatment of $\mathrm{Ca}+\mathrm{NAA}+$ Florissant-400 followed by $\mathrm{Ca}+\mathrm{NAA}+$ silicon, whereas the smallest flower diameter was found in control + silicon at postharvest for both seasons. Additionally, the combining of either NAA or $\mathrm{Ca}$ as preharvest applications plus all postharvest treatments induced highly significant increase in flower diameter when compared to control (+ either Florissant-400 or silicon at postharvest) in both seasons. The increase in flower diameter reflected the range of flowers opening during the displaying time. These results are coincided with those of El-Saka (2002) who stated that holding Rosa hybrida cut flowers in Florissant- $600+20 \mathrm{~g} / \mathrm{l}$ sucrose increased flowers development and quality.

\section{4- The percentage of increase in fresh weight during vase life}

The change in flower fresh weight expressed the flower freshness, flower longevity and senescence. Data presented in Table (2) clearly indicate that the change of flower fresh weight percentages was gradually increased due to the used pre- or postharvest treatments. In this concern, all pre- and postharvest treatments increased the percentages of flowers fresh weight which proved its superiority in the treatment of $\mathrm{Ca}+\mathrm{NAA}+$ Florissant-400 compared to control in both seasons. The pre- and postharvest treatments had fluctuative effects on the fresh weight percentages. In this regard, the flowers treated with NAA followed by $\mathrm{Ca}$ as preharvest plus Florissant400 at postharvest gave the heaviest flower fresh weight (3.24, 3.03 and 3.16, 2.82 $\%$, respectively) compared to the combination with silicon (3.15, 2.66 and 3.08, 2.42 $\%$, respectively) in both seasons. These results agreed with those of Khenizy et al (2009) on Moluccella laevis who found that pulsing basal ends of cut flowers in a solution containing sucrose $(30 \mathrm{~g} / \mathrm{l})+8$-HQC $(250 \mathrm{mg} / \mathrm{l})+\mathrm{Ca}(200 \mathrm{mg} / \mathrm{l})+\mathrm{Ca}^{+2}$ chelator $(E D T A)(30 \mathrm{mM} / \mathrm{l})+B A(25 \mathrm{mg} / \mathrm{l})$ was the most effective treatment for increasing the fresh weight percentage. El-Saka (2002) cleared that holding Rosa hybrida cut flowers in Florissant- $600+20 \mathrm{~g} / /$ sucrose was effective on enhancing flowers fresh weight. Also, Zaky (2008) showed that Florissant - $400(4 \mathrm{ml} / \mathrm{l})$ increased fresh weight of Eucalyptus leaves. 
Table 1. Effect of pre-and Postharvest treatments and their interactions on flower traits of 'Grand Prix' cut roses under room conditions during 2011\& 2012 seasons.

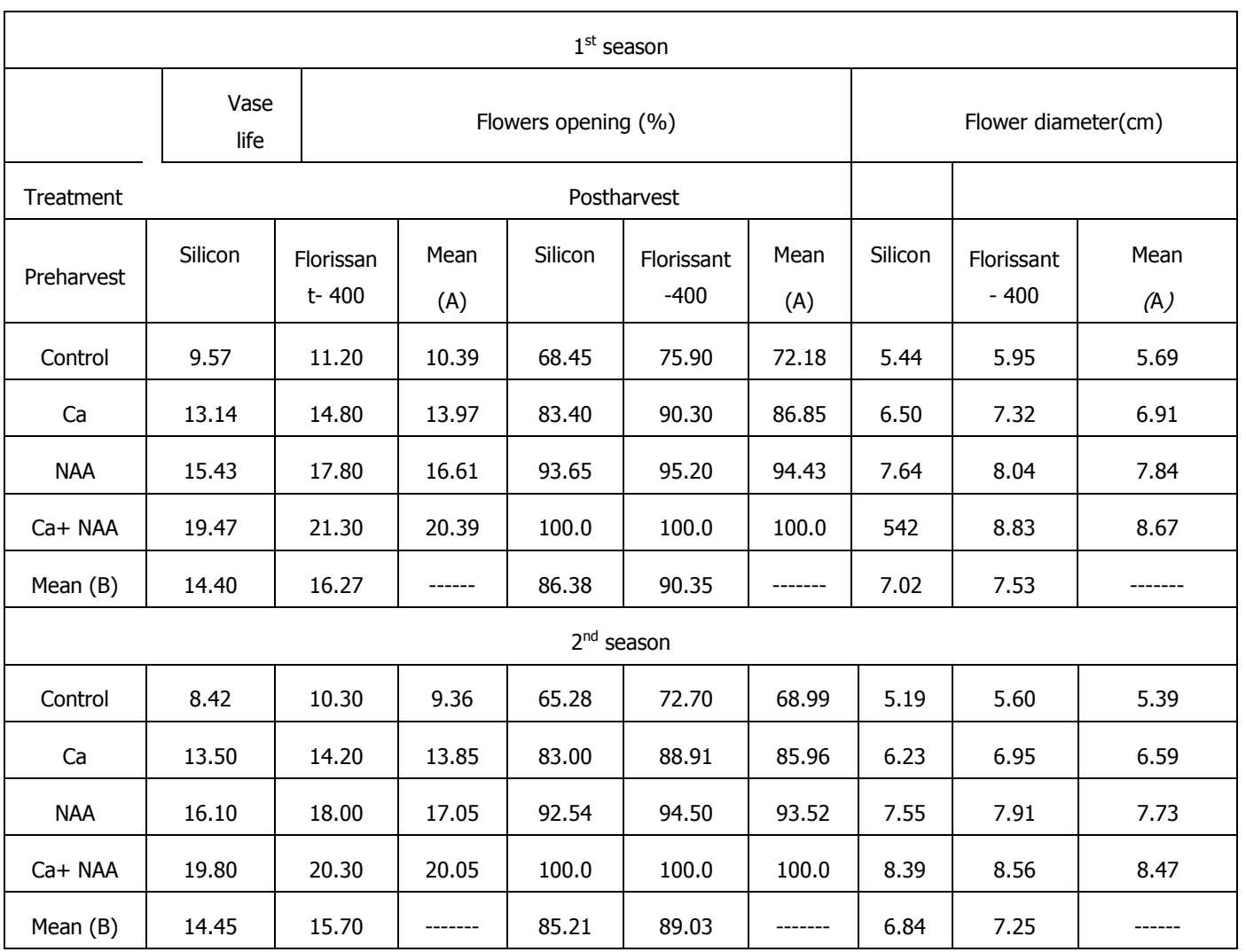

L.S.D at $5 \%$ level

\begin{tabular}{|c|c|c|c|c|c|c|c|c|c|}
\hline \multirow{2}{*}{$\begin{array}{l}\text { Traits } \\
\text { Factor }\end{array}$} & \multicolumn{3}{|c|}{ Vase life } & \multicolumn{3}{|c|}{ Flowers opening (\%) } & \multicolumn{3}{|c|}{ Flower diameter(cm) } \\
\hline & $\begin{array}{c}\text { Preharvest } \\
\text { (A) }\end{array}$ & $\begin{array}{c}\text { Postharve } \\
\text { st (B) }\end{array}$ & $A X B$ & $\begin{array}{c}\text { Preharvest } \\
\text { (A) }\end{array}$ & $\begin{array}{c}\text { Postharve } \\
\text { st } \\
\text { (B) }\end{array}$ & $A X B$ & $\begin{array}{c}\text { Preharve } \\
\text { st } \\
\text { (A) }\end{array}$ & $\begin{array}{l}\text { Postharve } \\
\text { st } \\
\text { (B) }\end{array}$ & AXB \\
\hline $1^{\text {st }}$ season & 1.97 & 1.39 & 2.79 & 5.17 & 3.66 & 7.32 & 1.84 & 1.30 & 2.60 \\
\hline $2^{\text {nd }}$ season & 1.98 & 1.40 & 2.80 & 5.33 & 3.77 & 7.54 & 1.83 & 1.30 & 2.60 \\
\hline
\end{tabular}

\section{5- Water uptake}

Data in Table (2) show differences in water uptake $\left(\mathrm{cm}^{3}\right)$ of Rosa hybrida cv. 'Grand Prix' when subjected to different treatments. The data cleared that all treatments increased the water uptake which ranged between 60.85 to $83.33 \mathrm{~cm}^{3}$ in 1st season and 59.38 to $79.96 \mathrm{~cm}^{3}$ in $2^{\text {nd }}$ one more than control (55.67 and 53.05 $\mathrm{cm}^{3}$, respectively) in both seasons. Furthermore, the significantly highest values of water uptake were obtained from the flowers treated with $\mathrm{Ca}+\mathrm{NAA}+$ Florissant-400 (86.67and $83.00 \mathrm{~cm}^{3}$, respectively) in both seasons. However, the second category was occupied by flowers treated with $\mathrm{Ca}+\mathrm{NAA}+$ silicon $\left(80.00\right.$ and $76.91 \mathrm{~cm}^{3}$, respectively) and the differences were significant compared with the other treatments used in both seasons. Also, the flowers which were held in a solution containing Florissant-400 at postharvest after pretreatment with either NAA or Ca led to a 
significant increment in water uptake compared with silicon in both seasons. These results are coincided with those of Khenizy et al (2009) on Moluccella laevis who pointed out that pulsing basal ends of cut flowers in a solution containing sucrose $(30 \mathrm{~g} / \mathrm{l})+8-\mathrm{HQC}(250 \mathrm{mg} / \mathrm{l})+\mathrm{ca}(200 \mathrm{mg} / \mathrm{l})+\mathrm{Ca}^{+2}$ chelator $($ EDTA $)(30 \mathrm{mM} / \mathrm{l})+\mathrm{BA}$ $(25 \mathrm{mg} / \mathrm{l})$ gave the highest water uptake. Zaky (2008) on Eucalyptus leaves showed also, that Florissant - $400(4 \mathrm{ml} / \mathrm{l})$ increased water uptake.

Table 2. Effect of pre-and Postharvest treatments and their interactions on flower traits of 'Grand Prix' cut roses under room conditions during 2011\& 2012 seasons.

\begin{tabular}{|c|c|c|c|c|c|c|}
\hline \multicolumn{7}{|c|}{$1^{\text {st }}$ season } \\
\hline \multirow{2}{*}{ Treatment } & \multicolumn{3}{|c|}{ Flowers fresh weight increase (\%) } & \multicolumn{2}{|c|}{ Water uptake $(\mathrm{cm})^{3}$} & \\
\hline & \multicolumn{6}{|c|}{ Postharvest } \\
\hline Preharvest & Silicon & $\begin{array}{l}\text { Florissant - } \\
\quad 400\end{array}$ & $\begin{array}{l}\text { Mean } \\
(\mathrm{A})\end{array}$ & Silicon & $\begin{array}{l}\text { Florissant } \\
-400\end{array}$ & $\begin{array}{l}\text { Mean } \\
\text { (A) }\end{array}$ \\
\hline Control & 1.53 & 1.85 & 1.69 & 53.48 & 57.87 & 55.67 \\
\hline $\mathrm{Ca}$ & 2.66 & 3.03 & 2.84 & 59.20 & 62.51 & 60.85 \\
\hline NAA & 3.15 & 3.24 & 3.19 & 64.42 & 72.50 & 68.46 \\
\hline $\mathrm{Ca}+\mathrm{NAA}$ & 3.54 & 4.05 & 3.79 & 80.00 & 86.67 & 83.33 \\
\hline Mean (B) & 2.72 & 3.04 & ------ & 64.28 & 69.89 & ------ \\
\hline \multicolumn{7}{|c|}{$2^{\text {nd }}$ season } \\
\hline Control & 1.40 & 1.77 & 1.58 & 50.80 & 55.30 & 53.05 \\
\hline $\mathrm{Ca}$ & 2.42 & 2.82 & 2.62 & 58.43 & 60.33 & 59.38 \\
\hline NAA & 3.08 & 3.16 & 3.12 & 61.85 & 69.76 & 65.81 \\
\hline $\mathrm{Ca}+\mathrm{NAA}$ & 3.33 & 3.89 & 3.61 & 76.91 & 83.00 & 79.96 \\
\hline Mean (B) & 2.55 & 2.91 & ------- & 62.00 & 67.10 & ------- \\
\hline
\end{tabular}

L.S.D at $5 \%$ level

\begin{tabular}{|c|c|c|c|c|c|c|}
\hline \multirow{2}{*}{$\begin{array}{l}\text { Traits } \\
\text { Factor }\end{array}$} & \multicolumn{3}{|c|}{ Flowers fresh weight increase (\%) } & \multicolumn{3}{|c|}{ Water uptake $(\mathrm{cm})^{3}$} \\
\hline & $\begin{array}{c}\text { Preharvest } \\
\text { (A) }\end{array}$ & $\begin{array}{c}\text { Postharvest } \\
\text { (B) }\end{array}$ & AXB & $\begin{array}{c}\text { Preharvest } \\
\text { (A) }\end{array}$ & $\begin{array}{c}\text { Postharvest } \\
\text { (B) }\end{array}$ & AXB \\
\hline $1^{\text {st }}$ season & 1.13 & 0.80 & 1.60 & 2.53 & 1.79 & 3.58 \\
\hline $2^{\text {nd }}$ season & 1.11 & 0.78 & 1.57 & 2.42 & 1.71 & 3.43 \\
\hline
\end{tabular}

\section{6- Bent-neck phenomenon (\%)}

For the main effect of different pre and postharvest treatments on bent-neck phenomenon \%, data in Figs (1\&2) illustrated that the preharvest treatment with control (+ either Florissant-400 or silicon at postharvest) had the highest percentage of bent-neck after 9 days with values higher than $86 \%$. Meantime, the individual preharvest treatment with either Calcium or NAA (plus either Florissant-400 or silicon 
at postharvest) significantly delayed bending symptoms in both seasons. Moreover, the combination of $\mathrm{Ca}+\mathrm{NAA}$ (+ either Florissant-400 or silicon at postharvest) recorded the highest delay for bending symptoms in both seasons. Generally, resistance of the peduncle to bending depends partially on the development of secondary thickening of the vascular system in the peduncle and its lignification and the thickening takes place at a relatively late stage of development of the flower bud. Also, the combined applications of auxin and gibberellin at the base of rose peduncles increased the phenylalanine ammonia lyase activity and through that the peduncle is strength end (Zieslin et. al., 1989). Therefore it is hypothesized that there might be a synergistic effect between the $\mathrm{CaO}$ and a-naphtalene acetic acid. In this connection, Amberger (1995) concluded that auxins are activating the "Calcium-channels". Ghanbari et. al. (2008) on rice mentioned that a high rate of silicon increased resistance to leaf and neck blast disease.

\section{7- Total sugars $(\%)$ in flowers}

Total sugars are important mainly for the energy metabolism. Data illustrated in Fig (3) demonstrate that all pre- and postharvest treatments increased the percentage of total sugars in flowers which proved its superiority in the treatment of $\mathrm{Ca}+\mathrm{NAA}+$ Florissant-400, whereas the least percentage of total sugars was obtained from the preharvest treatment with control + silicon at postharvest in both seasons. Meantime, all preharvest treatments plus Florissant- 400 recorded higher increase in the percentage of total sugars in flowers compared to the combination with silicon at postharvest in both seasons. This may be due to the reduction in respiration and metabolic rate of the flowers. Moreover, the preharvest treatment with NAA solely +Florissant-400 tended to the higher values of total sugars percentage followed by the combination with silicon as compared to $\mathrm{Ca}$ (+ either Florissant-400 or silicon at postharvest) in both seasons. These results are in line with El-Saka (2002) who found that holding Rosa hybrida cut flowers in Florissant- $600+20 \mathrm{~g} / \mathrm{l}$ sucrose was effective on increasing glucose content. Additionally, in cut roses that are limited by source activity, transport of promotive hormones from sinks to source tissues may regulate the processes associated with source activity such as photosynthesis, sucrose synthesis and phloem loading (Brenner and Cheikh, 1995). Ashraf (2008) on sugarcane cleared that chlorophyll contents, sugar and photosynthetic rate were significantly improved by the added calcium silicate.

\section{8- Anthocyanin (\%) in flowers}

Data illustrated in Fig. (4) show that treating Rosa hybrida cv. 'Grand Prix' flowers with the preharvest treatment with control and placing them in all tested vase solutions were less effective on increasing anthocyanin compared to treating the 
flowers with $\mathrm{Ca}$ and NAA either solely or in a combined mixture as preharvest treatments during the two successive seasons. Treating flowers with NAA at preharvest (+ either Florissant-400 or silicon at postharvest) increased anthocyanin content in flowers as compared with preharvest treatmen with Ca which reached the highest content with NAA+ Florissant-400 in the two seasons. In this respect, flowers treated with the preharvest treatments with Ca combined with NAA then placed in a preservative solution which contained Florissant-400 at postharvest had the highest anthocyanin content in both seasons. The above mentioned results coincided with those of Belanger (2008) who found that silicon feeding increases photosynthesis, chlorophyll content and other activities linked to the primary metabolism.

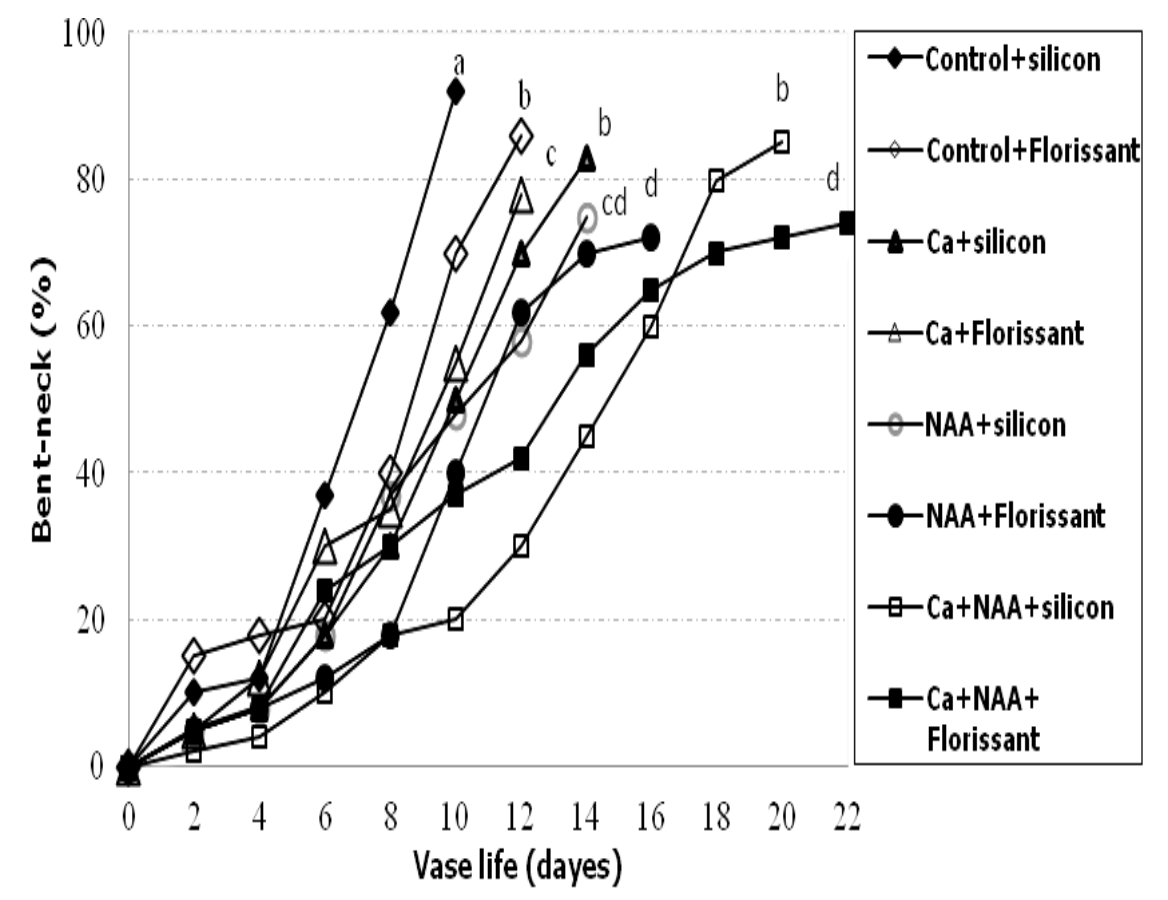

Fig. 1. Effect of pre-and postharvest treatments on bent-neck of 'Grand Prix' cut roses under room conditions during 2011. 


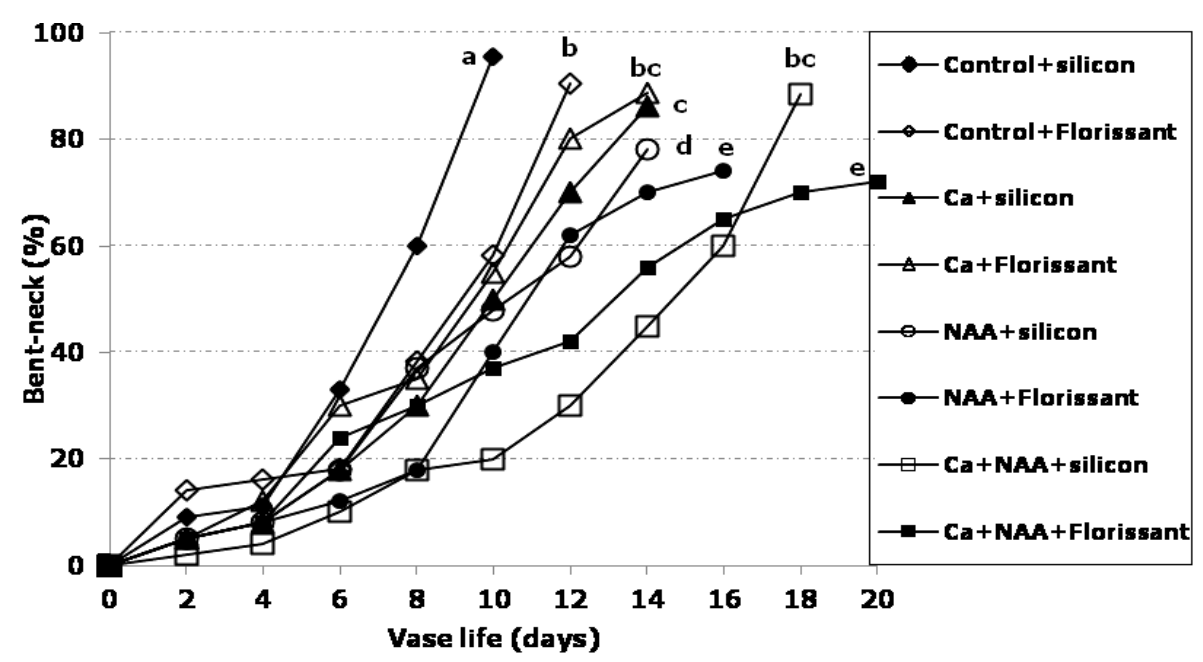

Fig. 2. Effect of pre-and postharvest treatments on bent-neck of 'Grand Prix' cut roses under room conditions during 2012.

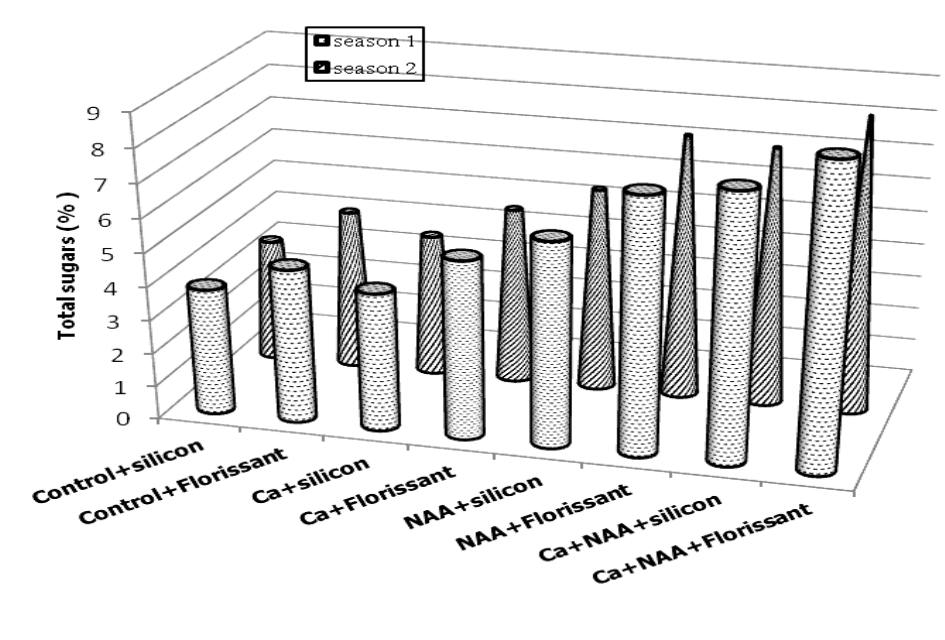

Fig. 3. Effect of pre-and postharvest treatments on total sugars (\%) in 'Grand Prix' cut roses under room conditions during 2011\& 2012. 


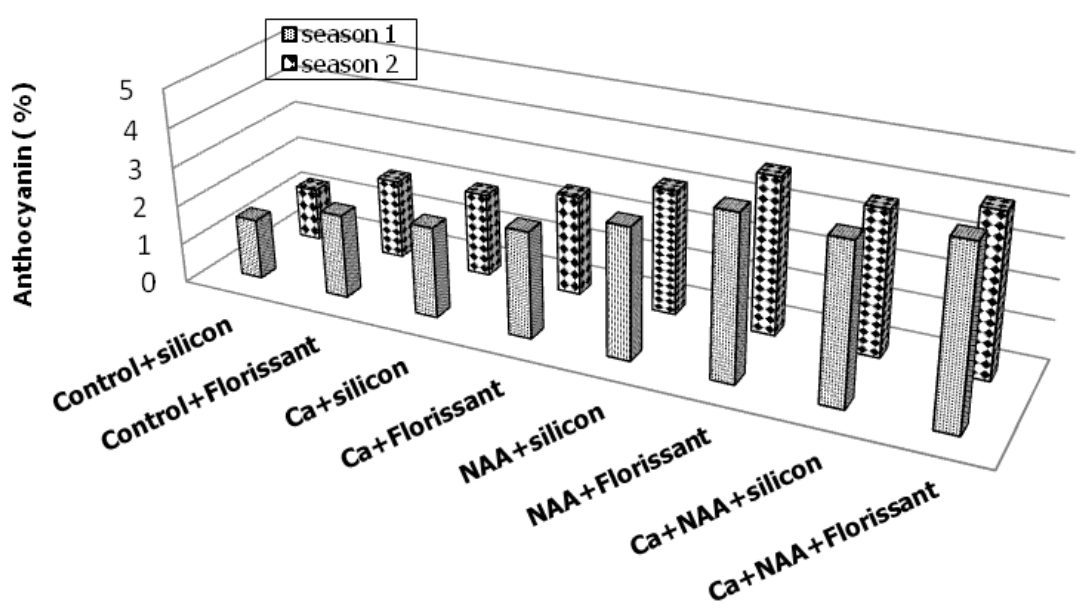

Fig. 4. Effect of pre-and postharvest treatments on anthocyanin (\%) in 'Grand Prix' cut roses under room conditions during 2011\& 2012.

\section{REFERENCES}

1. Abraham, A. O., M. D. Laing, J. P. Bower, and C. Clark. 2008. Preharvest or postharvest silicon treatment for the control of postharvest Penicillium digitatum of Citrus fruit. Proc.4th International Conference «Silicon in Agriculture», 26-31 October, Wild Cost Sun, Transkei, South Africa.

2. Amberger, A. 1995. Pflanzenernahrung. Verlag Ulmer Stuttgart-Germany.

3. Ashraf, M. 2008. Silicon-mediated alleviation of salt stress effects in sugarcane genotypes differing in salinity tolerance. Proc. 4th International Conference «Silicon in Agriculture», 26-31 October, Wild Cost Sun, Transkei, South Africa.

4. Belanger, R. R. 2008. Understanding the benefits of silicon feeding in plants through transcriptomic analyses. Proc. 4th International Conference «Silicon in Agriculture», 26-31 October, Wild Cost Sun, Transkei, South Africa.

5. Bolivar, P., G. Fischer, V.J. Florez and A. Mora. 1999. Effect of pre- and postharvest treatments on flower longevity of 'Ariana' cut roses. Acta Horticulturae, 482: 83-87.

6. Brenner, M. L. and N. Cheikh. 1995. The role of hormones in photosynthate partitioning and seed filling. In: P. J. Davies (ed.). Plant Hormones. Kluwer Academic Publishers, London. p. 649-670.

7. Dubois, M. K., A. Gilles, J.K. Hamilton, P.A. Reders and F. Smith. 1956. Colorimetric method for determination of sugars and related substances. Analytical Chemistry, 28(3):350-356. 
8. El-Saka, M. M. 2002. Physiological studies on flowers opening and keeping quality of rose , carnation and gladiolus. Zagazig J. Agric Res., 29 (1): 115128.

9. Ferrante, A., S. A. Mensuali, G. Serra and F. Tognoni. 1998. Ethylene production and vase life in cut Eucalytus sp. foliage. Italus. Hortus., 5:57-60.

10. Ghanbari M. A., H. R. Mobasser and V. Alavi. 2008. Effect of silicon and nitrogen rates on leaf and neck blast, chlorophyll content and yield of rice (Oryza sativa I.) In two water management systems (flooding and deficit irrigation) in the North of Iran. Proc. 4th International Conference «Silicon in Agriculture», 26-31 October, Wild Cost Sun, Transkei, South Africa.

11. Halevy, A. H. 1979. Senescence and postharvest physiology of cut flowers, part 1. Hort. Rev., 1: 204-236.

12. Husia, C.L, B.S. Luh and C.D. Chichester. 1965. Anthocyanin in free stone peaches. J. Food Sci., 30: 5- 12.

13. Khenizy, S. A. M., B. A. El- Sayed and G. H. Abdel Fattah. 2009. Inhibition of the gravitropic response of Moluccella laevis $\mathrm{L}$. cut spikes by calcium chelators (EDTA). Minufiya J. Agric. Res., 34 (4): 1613-1647.

14. Marschner, H. 1986. Mineral Nutrition of Higher Plants. Academic Press, London.

15. Michalczuk, B., D. Goszczynska, R.D. Rudnicki, and A.H. Halevy. 1989. Calcium promotes longevity and bud opening in cut rose flowers. Israel J. Bot., 38:209215.

16. Snedecor G.W. and W. G. Cochran. 1989. Statistical Methods. $7^{\text {th }}$ d. The Iowa State Univ. Press Ames. Iowa, USA.

17. Van Doorn, W. G. and A. D. Stead. 1997. Abscission of flowers and floral parts. J. Exp. Bot., 48 (309): 821-837.

18. Zaky A. A. 2008. Effect of some ethylene inhibitors and some growth regulators on vase life and keeping quality of cut Eucalyptus leaves. Egypt. J. Hort., 86 (6): 2379-2391.

19. Zieslin, N., F. Starkman and E. Zamski. 1989. Bending of rose peduncles and the activity of phenylalanine ammonia lyase in the peduncle tissue. Plant Phys. Biochem., 27(3): 431-436. 
تأثير معاملات ماقبل الحصاد وما بعده على إطالة عمر أزهار الورد المقطوفة صنف

\section{'Grand Prix'}

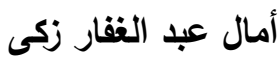

قسـم بـحوث نباتات الزينة و تنسيق الحدائق - معهد بحوث البساتين - مركز البحوث الزراعية- الجيزة - مصر -

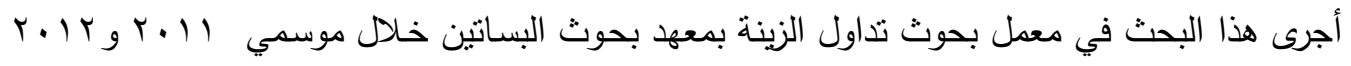

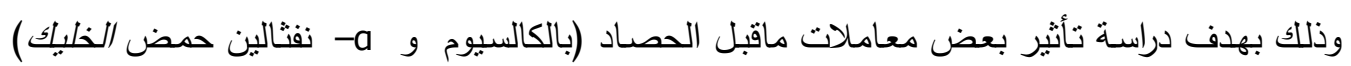

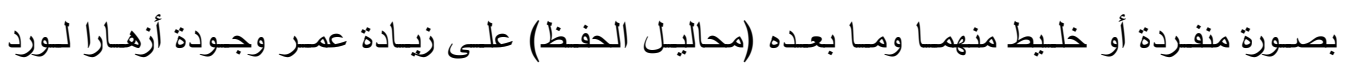

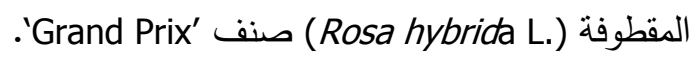

$$
\text { وقد أظهرت النتائج الأتي : }
$$

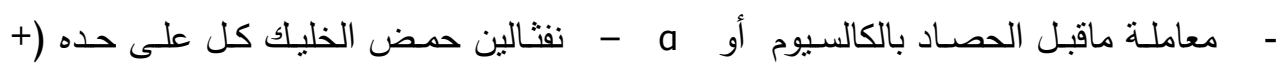

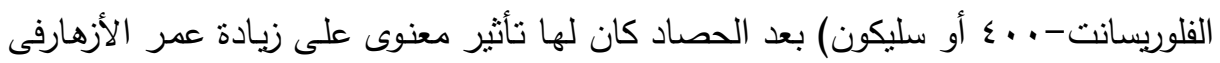
الفازة وزيادة نسبة تفتحها كما أدت إلى زيادة امتصاص بلى الماء.

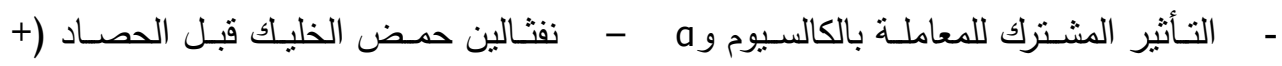
الفلوريسانت- . .ع) كان لـه أثراً متقيزاً على زيـادة عمر الأزهارفى الفـازة و قطر الأزهار

$$
\text { والوزن الطازج لها. }
$$

- أدت معاملة الكنترول قبل الحصاد (+ الفلوريسانت- - .ـ أو سليكون) بعد الحصاد إلى أعلى

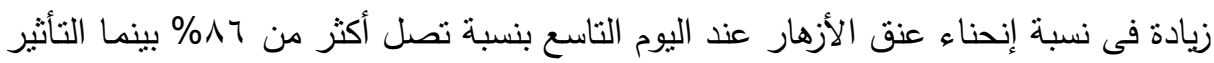

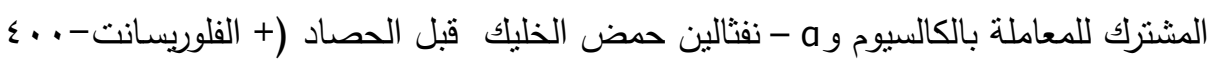
أو سليكون) بعد الحصاد حقق أعلى نسبة تأخير لآنحناء عنق الأزهار .

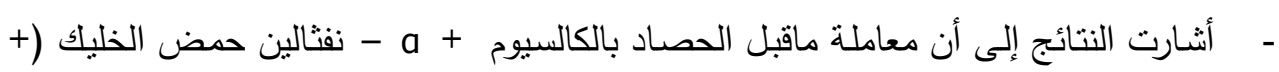

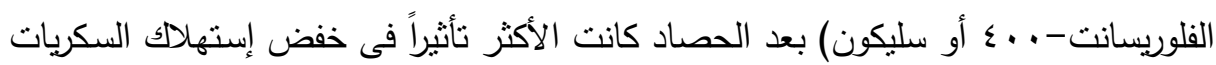
وزيادة محتوى الأزهار من صبغة الأنثوسيانين.

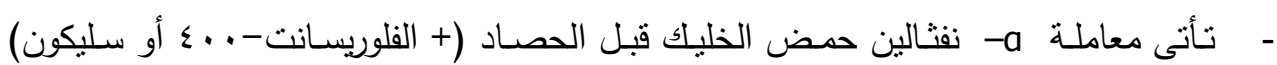
بعد الحصاد فى المرتبة التانيه فى نأثيرها على الصفات المدروسة وبالتالى حفظ جودة الأزهار مقارنة بالمعاملات الأخرى أو الكنترول. الكلمات الدالة : أزهار الورد المقطوفة - معاملات ماقبل الحصاد وما بعده - عمر الأزهار فى الفازة

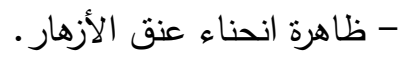

